\title{
New Entomocoenotic Particularities and Integrated Pest Control in Transylvanian Wheat Crops Under the Impact of Climate Warming
}

\author{
Dana MALSCHI ${ }^{1,2 *}$, Felicia MUREŞANU ${ }^{2}$, Rozalia KADAR², Adina Daniela TĂRĂU ${ }^{2}$, \\ Ana-Maria PĂCURAR ${ }^{2}$, Cornel CHEŢAN² ${ }^{2}$ Nicolae TRITEAN ${ }^{2}$ \\ ${ }^{1}$ Babeş-Bolyai University, Environmental Science and Engineering Faculty Cluj-Napoca, Fântânele str., \\ No. 30, Cluj County, România. \\ ${ }^{2}$ Agricultural Research-Development Station Turda, Agriculturii str., No. 27, Cluj County, România. * \\ *corresponding author: danamalschi@yahoo.com
}

Bulletin USAMV series Agriculture 71(2)/2014

Print ISSN 1843-5246; Electronic ISSN 1843-5386

DOI 10.15835/buasvmcn-agr: 10885

\begin{abstract}
Based on the entomological research at the ARDS Turda, the paper presents new research on pest abundance in wheat crops in relation to the climate warming in Transylvania and the adequate integrated pest control methods under different cultural soil technologies: classical (ploughing) and conservative (no tillage), in open field and in agroforestry belts agroecosystems. During 2007-2014, the study has revealed data on species composition and dynamics. Species determination has been achieved based on the samples performed every 10 days, by 100 double sweep-net catches. Were pointed out major outbreaks of abundance of thrips (Haplothrips tritici), as eudominant species; of wheat flies (Chloropidae and Anthomyiidae); stem flea beetles (Chaetocnema aridula); leafhoppers (Javesella pellucida, Psammotettix alienus etc.) and aphids (Sitobion avenae etc.), as dominant groups; cereal bugs (Eurygaster maura, Aelia acuminata); Coleoptera: Agriotes, Zabrus tenebrioides etc. Due to aridization and climate warming, the critical attack moments have been recorded 3-4 weeks earlier and overlapped. IPM recommends special attention to preventing measures for flies, leafhoppers, aphids, etc., which shows a high biological potential: optimal sowing time, agrotechnical methods, seed treatment with systemic insecticide and complex plant protection measures. The results proved the importance of insecticide applications: at the end of tillering phase (1333 DC stage) and at the flag-leaf appearance and ear emergence in 45-59 DC stage. At the first treatment, cereal flies, fleas, leafhoppers, thrips, bugs etc. are controlled simultaneously, by recommending the shock (pyrethroids) or systemic insecticides (neonicotinoid etc.). At the second treatment, the ear pests are controlled simultaneously and it is recommended the shock insecticides (pyrethroids etc.) with reduced effects on the useful entomophagous. The IPM is a major section of successive soil no tillage technologies, comprising a special pest control strategy, with insecticides application on seed treatment and in 2-3 successive treatments in vegetation. Entomophagous populations are particularly abundant in open field area, in classic and in soil no tillage technologies. In the farming system with protective agro-forestry belts-favorable for increasing of entomophags species, the research pointed out the efficiency of biological control, only using the entomophagous natural resources.
\end{abstract}

Keywords: integrated pestcontrol, protective agro-forestry belts, soil no tillage technology, useful entomophagous arthropod fauna, wheat pests

\section{INTRODUCTION}

Integrated pest management (IPM) is an agroecological system approach to crop protection that uses different practices to control the pest and minimize the pesticide applications (Baicu, 1996; Bărbulescu and Popov, 2001; Malschi, 2009; Popov et al., 2009).
Practicing IPM involves the following steps: - Weather forecasting to evaluate the risk of pest outbreaks. - Monitoring dynamics and attack level of pest populations; determining the thresholds of economical damage. - Culture controls methods: soil preparation, using certified seeds. - Biological controls: entomophagous predators and parasites, 
biological products and natural resources. Chemical controls: using insecticides, only recommended if the biological methods fail and the threshold limit has been surpassed. - Record keeping: used to predict the attack (FAO, www. fao.org/agriculture/crops/core-themes/theme/ pests/ipm/; Bărbulescu et al., 2001, 2002; Malschi, 2007; Popov, 1979; Popov et al., 2000, 2007, 2010; Wetzel, 1995).

Common Agricultural Policy specifying the importance of providing environmental public goods associated with agriculture and environment - such as agricultural landscapes, farmland biodiversity, soil, water and air quality, climate stability. Also, special public goods are associated with agriculture practices of integrated pest management such as: the positive impact of integrated pests control, biological pest control, conservation of biodiversity of entomophags and useful flora, biological agriculture, related to pollution limitation and sustainable development of environmental quality; the impact of using soil conservative systems with minimum tillage and no tillage, in water stressed areas, related to climate stability etc. (Cooper et al., 2009; Carlier et al., 2006; Guș and Rusu, 2008; Malschi, 2009).

Long-term research on sanitary state of the field crops underlying the development of pest control technologies suitable of climate change and aridization (Popov et al., 2003, 2006; Popov and Barbulescu, 2007; Malschi, 2007, 2008, 2009). The study performed from 1980 showed the evolution of main cereal pest such as: Diptera, Homoptera, Thysanoptera, Coleoptera etc. at the Agricultural Research and Development Station Turda, in Central Transylvania (Malschi 2007, 2008,2009 ). During 2007-2014 period, especially under the conditions of profound agro-ecological changes caused by climate warming and also under the new technological conditions in regional agricultural exploitations, the integrated control strategy of wheat pest was elaborated (Malschi et al. 2012, 2013 a, b, c).

\section{MATERIAL AND METHODS}

Based on the entomological research at the Agricultural Research-Development Station Turda the paper presents an agro-ecological study on the population dynamics of wheat pests and the adequate integrated pest control methods under different cultural soil technologies: classical (by ploughing) and conservative (by soil no tillage), in open field agricultural system and in agroforestry belts farming system, in relation to increased pest abundance and attack, on the current agroecological changes, in Transylvania.

During 2007-2014, the study has revealed data on species composition and dynamics in wheat crops. Species determination has been achieved based on the abundant samples, performed every 10 days. The analysed samples have been obtained by the method of captures in 100 double sweepnet catches, for the arthropod fauna at the plant level. The structure and dynamics of the pest species populations interacting with predatory arthropod fauna have been studied in wheat crops. The research objectives have comprised aspects of interest such as: systematic and bio-ecological study of pest species; danger of attack expansion; elaboration of agro-ecologically integrated pest control strategy in accordance with technological factors: - selective, efficient insecticides, agrotechnical methods; biotic factors: - natural entomophags and environment protection factors.

\section{RESULTS AND DISCUSSION}

The changes in the level of regional climate, represented by warming and excessive draught, especially in spring have caused the burst of pest populations which may cause important damages to wheat crops. In the last years of climate heating were recorded changes in the pest structure. Were pointed out major outbreaks of attack of thrips (Haplothrips tritici), as eudominant species; aphids (Sitobion avenae, Schizaphis graminum, Rhopalosiphum padi, Metopolophium dirhodum); leafhoppers Uavesella pellucida, Psammotettix alienus, Macrosteles laevis); cereal flies (Chloropidae: Oscinella frit, Meromyza nigriventris, Elachiptera cornuta etc. and Anthomyidae: Delia coarctata, Phorbia securis, Ph. penicillifera); stem flea beetles (Chaetocnema aridula), as dominant species; bugs (Eurygaster maura, Aelia acuminata) etc (Fig. 1).

During 2007-2013, are highlighted: eudominant wheat thrips, dominant wheat flies, wheat fleas, aphids and leafhoppers (Fig. 1). It is considered the dominance classes as: Eudominant: 32 to $100 \%$; Dominant: 10 to 31,9\%; Underdominant: 3,2 to 9,9\%; Reported: 1 to 3,1\%; Low reported: 0,32 to $0,99 \%$; Handover: $<0,32$ $\%$ (Wetzel, 1995). The average of pests structure 


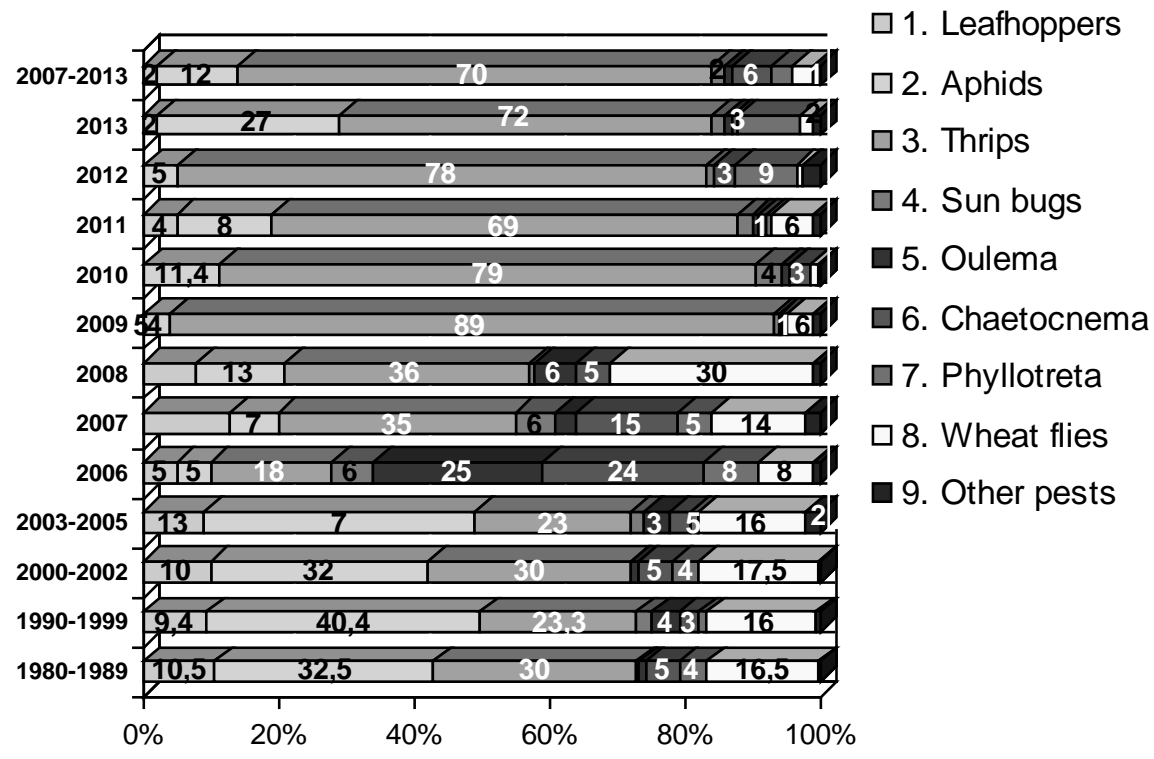

Fig. 1. Dynamics of wheat pests structure (\% Dominance) in 1980-2013, at ARDS Turda.
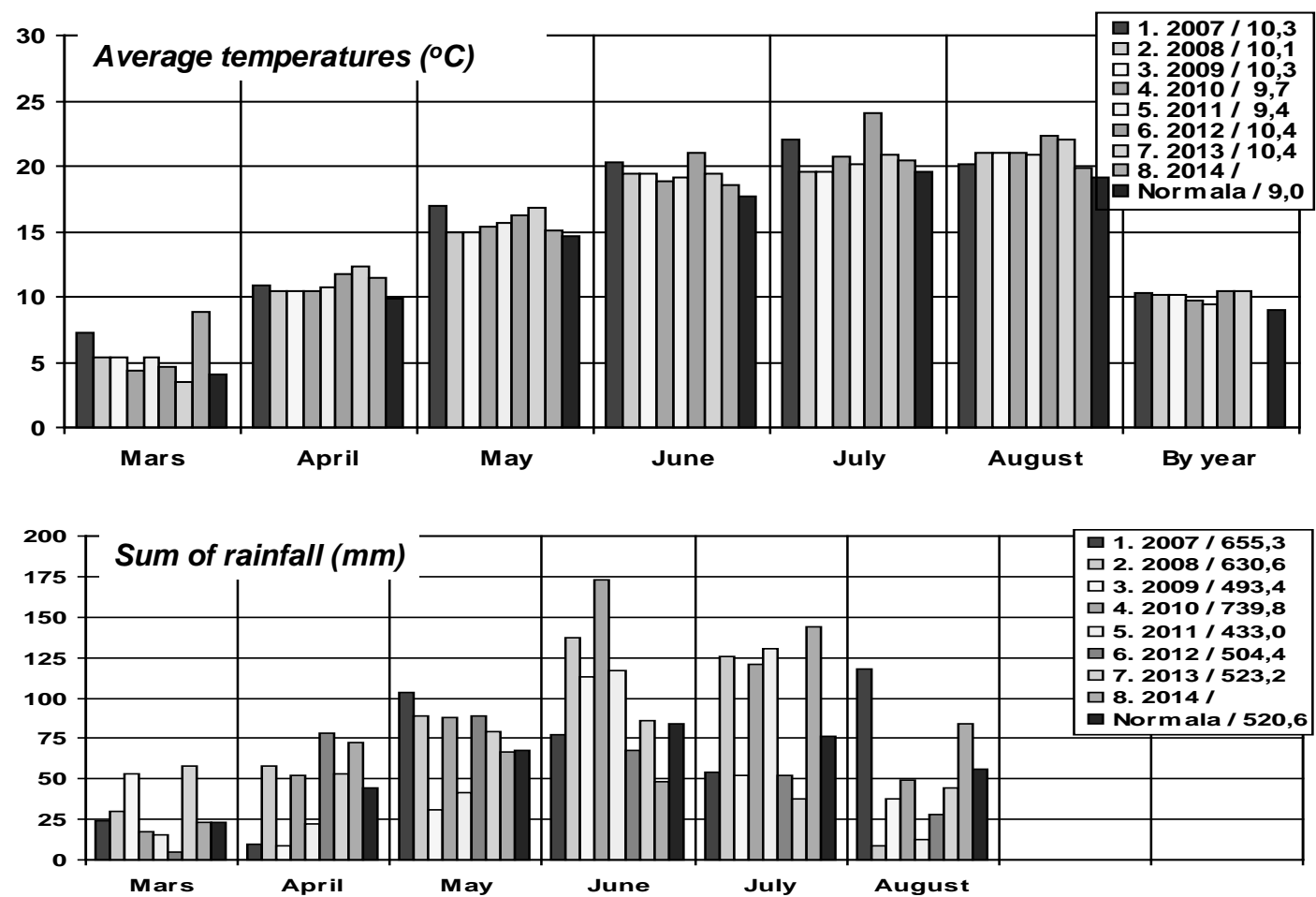

Fig. 2. Average temperatures and sum of rainfall at Turda conditions by month, from March to August and by year, in 2007-2014 (ARDS Turda) 
show: $70 \%$ for thrips, $12 \%$ for aphids and 2\% for leafhoppers, $3 \%$ for Diptera, only $1 \%$ for cereal leaf beetles and $9 \%$ for cereal fleas, $2 \%$ for cereal bugs and to $1 \%$ for wire worms and other pests. Compared to the structure of wheat pests in a prior period there was an increase of the percentage share of thrips and wheat fleas which frequently records population explosions. Besides these, cereal bugs in some years reached dangerous densities in culture. Is remarkable the decrease in the percentage share of wheat flies, leafhoppers, aphids, leaf beetles that were dominant in the structure in the period 19802000. But is still important the attack potential of Diptera, leafhoppers and aphids.

Biological potential and the attack of the main pests of wheat were related to climate change (Fig. 2), to species biology and to phenological development of crops in the current technological change.

In open field area, these changes on the structure and populations abundance of referred pest species is a dangerous risk situation of wheat crops. A diminish in the species range and an increase of the population abundance have been recorded in the main pests, especially in the monovoltin species (Haplothrips tritici, Delia coarctata, Phorbia penicillifera, Chaetocnema aridula, Eurygaster maura, Aelia acuminata, Zabrus tenebrioides etc. An increase of the population abundance have been recorded for some polivoltine species of Diptera Chloropidae (Oscinella frit, Elachiptera cornuta, Meromyza nigriventris etc.) and Anthomyiidae (Phorbia securis, Delia platura), for leafhoppers and aphids. Due to aridization and climate warming, the critical attack moments have been recorded 3-4 weeks earlier and overlapped. So, the integrated pest management should include specific measures for these dangerous pests of wheat in central Transylvania. In open field agricultural system, comparative research on the abundance and structure of wheat pests in classical and conservative soil technologies proved a greater abundance and importance of the populations of thrips, flies, aphids, leafhoppers, wireworms reached at conservative no tillage technology (Fig. 3 and 4). Haplothrips tritici is the most abundant and important pest of wheat in classical (by plowing) and conservative (by minimum soil tillage and no tillage) technologies. So thrips as well as aphids and leafhoppers are the dangerous vectors for viruses and other pathogens, favoring their attack.

By practicing successive no tillage conservative soil technologies, recommended for the current conditions of climate aridity in Transylvania, were increased the main pest populations and were accumulated higher biological reserve of thrips, Chloropidae, leafhoppers, aphids and soil pests (wireworms Agriotes sp. etc.). So, in recent years

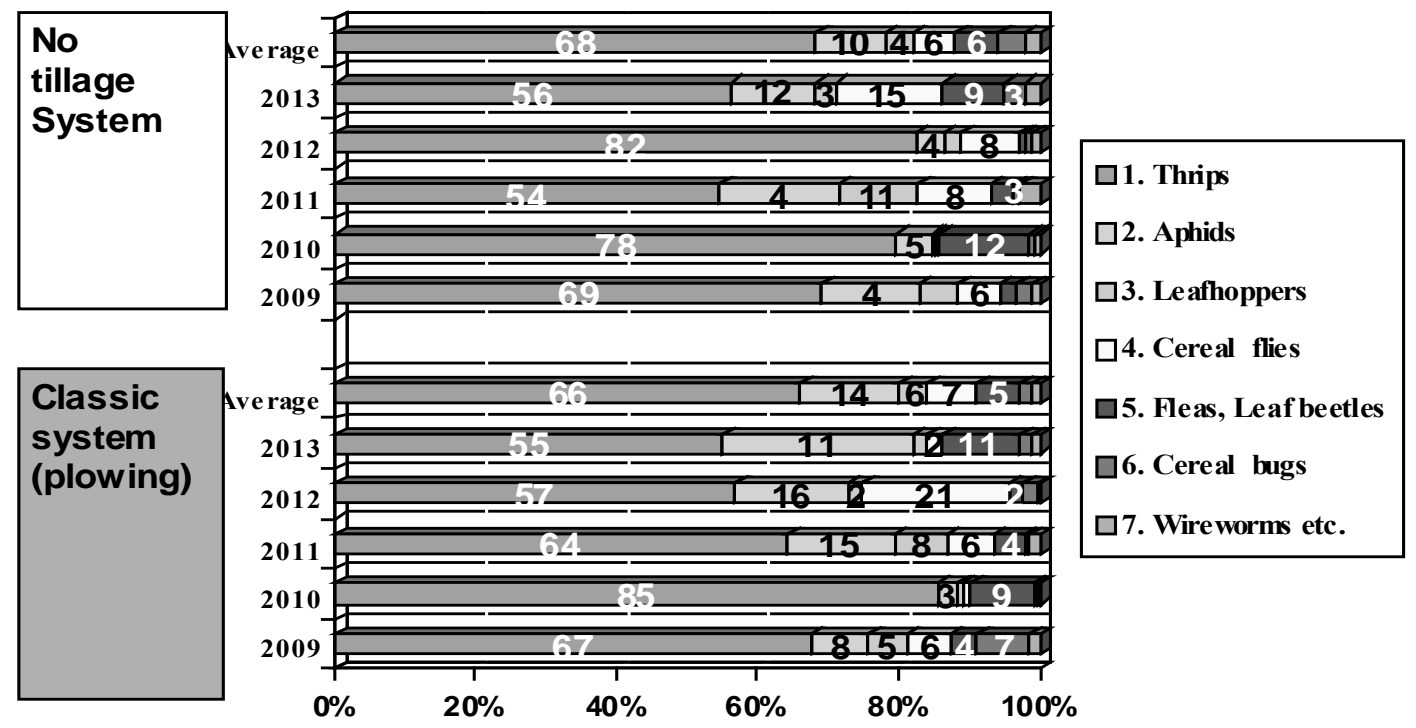

Fig. 3. Dynamics of structure (\%) of pests in wheat crops, in classic and in no tillage system, at ARDS Turda, in 2009-2013 
2009-2013 (Fig. 3) Haplothrips tritici - reached at $68 \%$; flies: $6 \%$; aphids: $10 \%$; leafhoppers 4 $\%$, wheat fleas $6 \%$, cereal bugs $4 \%$ in the pest structure, showing an important attack potential. The pests have achieved $86 \%$ and entomophagous $14 \%$ in the structure of entomofauna of no tillage crops in open field area.

In wheat fields with classical plowing system cereal flies achieved $7 \%$, aphids $14 \%$, leafhoppers $6 \%$, more then in no tillage system, also Haplothrips tritici - reached at $66 \%$ and the sun bugs reached at $2 \%$. The entomophagous achieved at $16 \%$ more then in no tillage system (Fig. 4).

An entomocenotic balance was maintained in agroforestry belts farming system of Cean Bolduţ, also similar to the values in the last three decades (1980-2010) (Figure 1). The wheat pests had a structural share of $75 \%$ and the entomophagous achieved $25 \%$, on the favourable conditions due to the forestry belts. Thrips showed $30 \%$ only and flies $25 \%$, aphids $17 \%$, leafhoppers $5 \%$ in the pest structure (Fig. 5 and 6).

In 2010-2013, the abundance of pests in the the open system was 1,7 times higher than in the farm with protective forestry belts (Fig. 7 and 8).
Report on phytophagous / entomophagous was 7 / 1 in the open field system and only 4,7 / 1 in the the farm with forest belts for protection. That can explain the appearance of massive development of wheat thrips, fleas, leafhoppers, aphids, etc. and the critical attack situations in the open field system. The mentioned species abundance is a risk situation on wheat crops, which requires special measures for pests control, especially in open field area. As a result, preventive control measures and insecticide treatments of seed and of crop vegetation, on the critical moments of risk overlapping are very important (Fig. 7). The applied integrated pest management on favourable agroecological conditions in the farm with protective forestry belts, in Cean-Boldut (Fig. 8), shows the efficiency of biological control (tab. 1 ), using the entomophagous natural resources, without insecticides (Malschi, 2009; Malschi et al., 2010).

In order to provide a sustainable development of winter wheat crop, the adequate prevention and control measures have been required, specifying the correct times for the application of insecticide treatments.

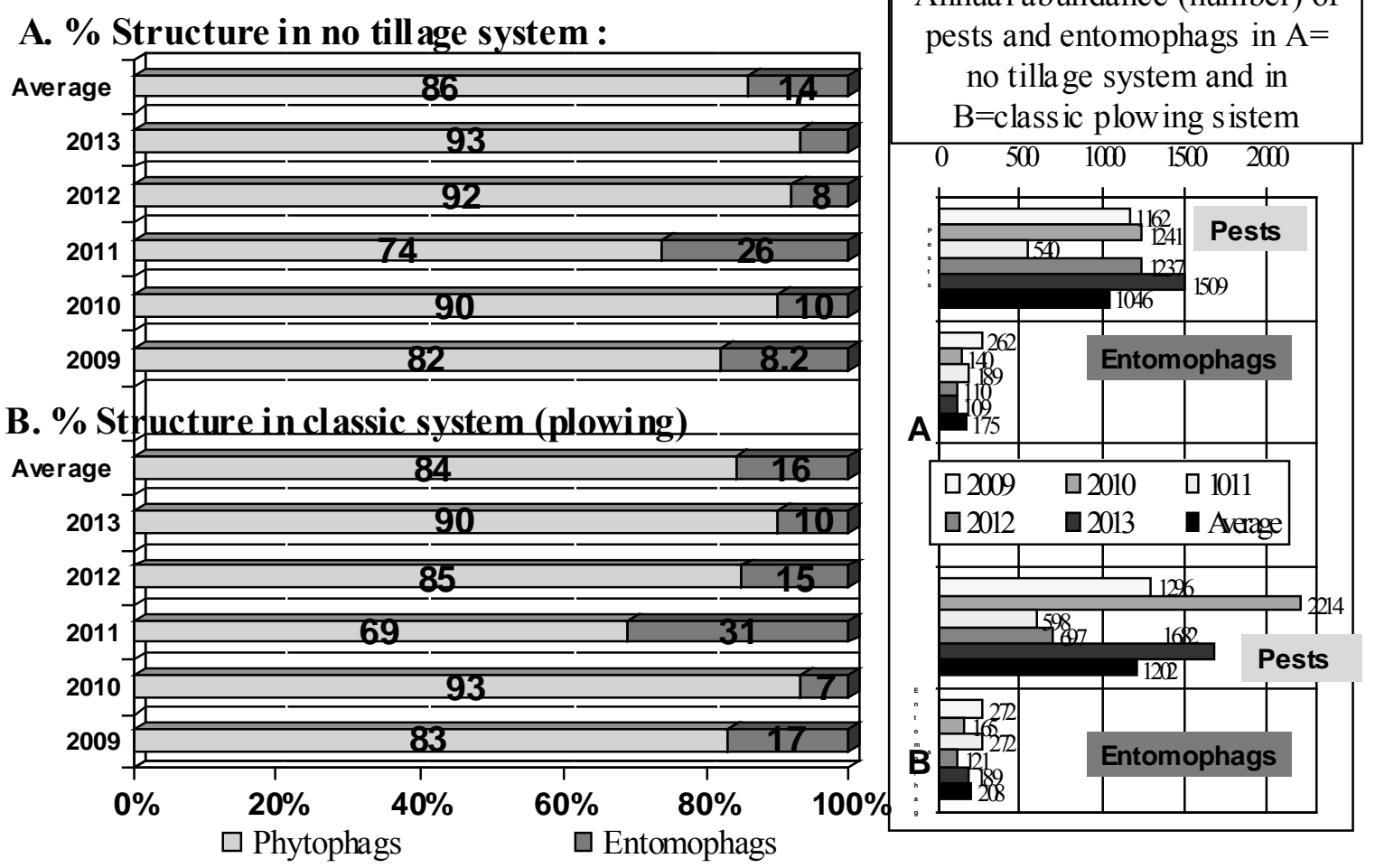

Fig. 4. Dynamics of structure (\%) and abundance of wheat pests and entomophags, in classic and in no tillage system, ARDS Turda, 2009-2013 


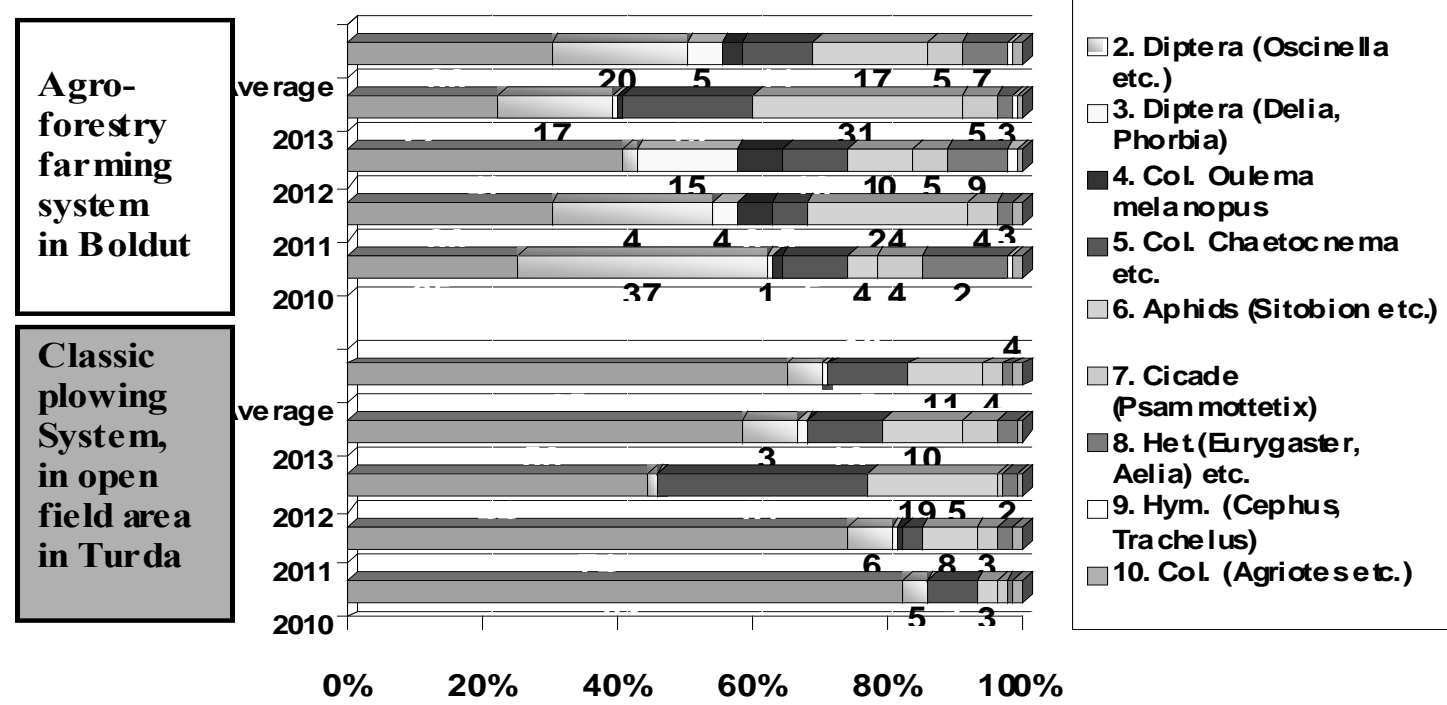

Fig. 5. Dynamics of \% structure of pests in wheat crops in open field area in Turda and in the agro-forestry farm in Cean-Bolduţ , 2010-2013, ARDS Turda

A. \% Structure in agro-forestry farm in Boldut

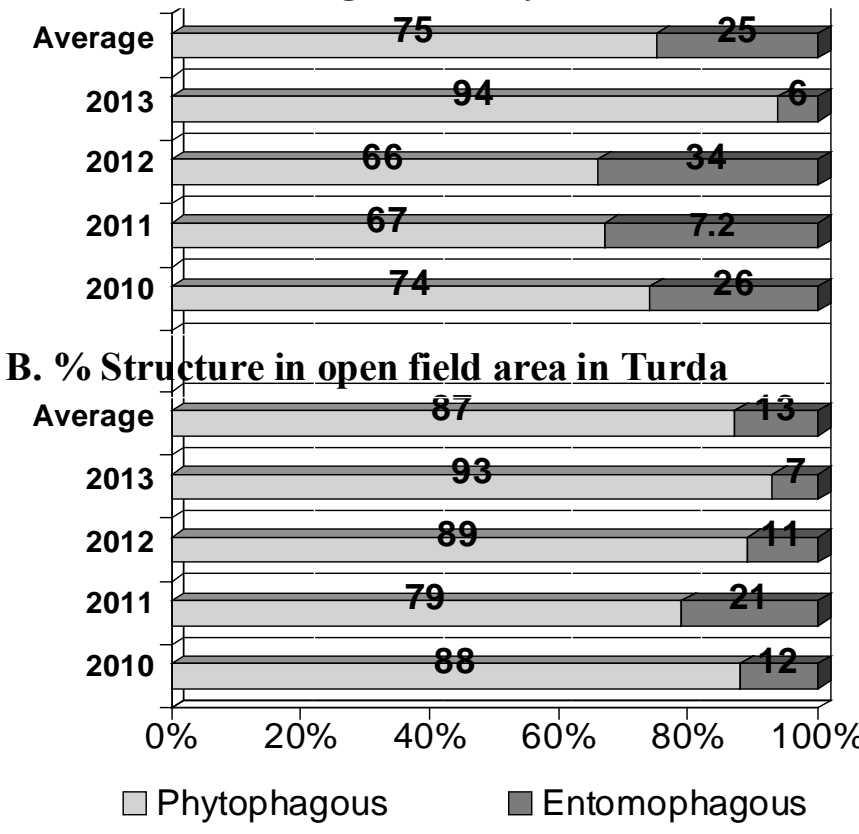

Abundance of wheat pests and entomophags (number) in

$\mathrm{A}=$ Boldut farming system with forestry belts and in

$\mathrm{B}=$ Turda open field sistem

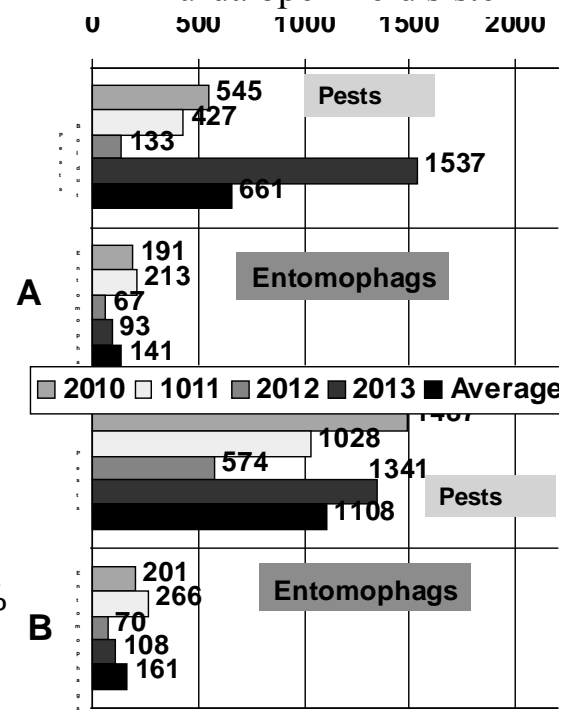

Fig. 6. Dynamics of structure (\%) of wheat pests and entomophagous in open field area in Turda and in the agro-forestry farm in Cean-Bolduţ, 2010-2013, ARDS Turda. 


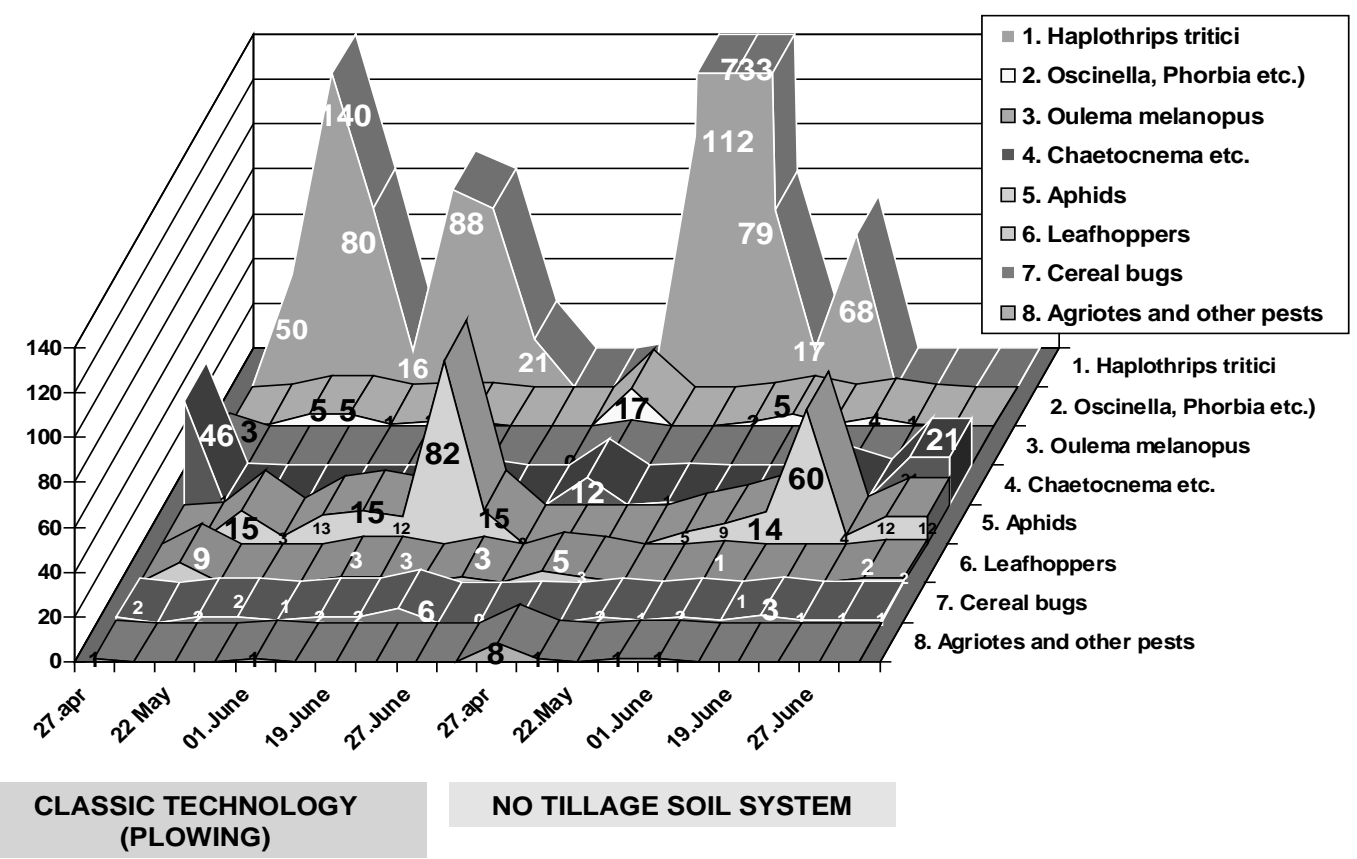

Fig. 7. Occurrence and dynamics of wheat pests, in classic plowing and conservative no tillage soil technology, in 2012, at ARDS Turda. (Nr./100 sweep net catches)

Fig. 7. Occurrence and dynamics of wheat pests, in classic plowing and conservative no tillage soil technology, in 2012, at ARDS Turda. (Nr./100 sweep net catches)

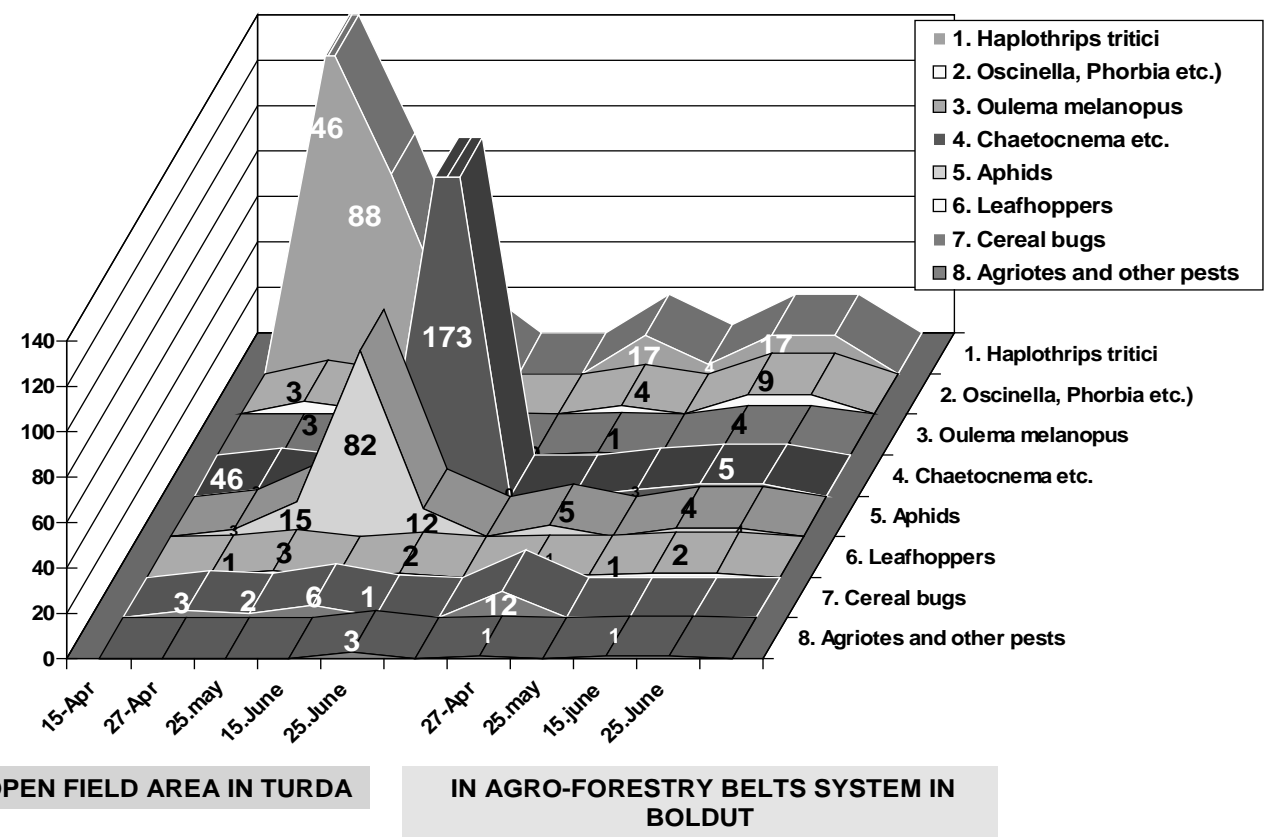

Fig. 8. Occurrence and dynamics of wheat pests in open field area in Turda and in the agroforestry farm in Cean-Boldut, in 2012, ARDS Turda.(Nr. / 100 sweepnet catches)

Fig. 8. Occurrence and dynamics of wheat pests in open field area in Turda and in the agro-forestry farm in Cean-Bolduț, in 2012, ARDS Turda.(Nr. / 100 sweepnet catches) 
Favored by the warmest years, the wheat thrips population explosions were manifested especially in the years with more abundant precipitation in May and June. The optimal time of insecticidal treatment for thrips control is between 10 to 20 May. The aphids and leafhoppers manifest a population increases particularly related to their favorable development in May and in summer to the volunteer plants, grasses and to other crops, becoming of dangerous as vectors of wheat yellow dwarf, especially for the early sowing crops. Wheat flies of the genus Phorbia, Delia, Opomyza were disadvantaged of the aridity, warm and drought periods in the spring months. The same conditions related with delayed phenological development of wheat were favorable, however, to the Chloropidae species. They can become of dangerous for early autumn sowing crops. Wheat fleas (Chaetocnema, Crepidodera) were shown an increase in abundance of populations, very dangerous in early spring and in April, damaging as Diptera larvae. It appears that the high temperatures from April to May have decreased cereal leaf beetles (Oulema sp.) larvae populations.

The efficiency of integrated pest control methods has been carried out under different lots of crop technologies: in open field area (in classical plowing and in conservative no tillage system) and in the agro-forestry belts farming system (Tab. 1, 2, 3). Within the testing experiments of efficient insecticides, optimal application time, an integrated pest management has been studied including herbicides, fungicides, fertilizers applications etc.

In open field agricultural system, the integrated pest control, needs special attention on: analysis of zone and crop climate in interrelation with the periodical observation of attack potential (at crop emergence, in the spring at tillering and in the 2nd decade of May, at flagleaf appearance and ear emergence); - the use of agro-technological measures (the sowing in the second half of October, the volunteers wheat destruction, the balanced fertilization, herbicide treatment and others); - periodical multi-annual observation of the pests interactions with auxiliary entomophags; - insecticide treatment on seeds and on vegetation; - predator populations enrichment and protection by careful treatment application on vegetation, by protection of entomophag refuge sites (development of flowering plants of crop borders, protection of marginal flora biodiversity, protective agroforestry belts etc.).

Insecticide application should be carried out when the economic damage thresholdvalues of pest have been exceeded. Also, insecticide application is recommended taking into account the activity of the natural reserve of predatory and parasite entomophags. Especially, the natural predators play an important role in decreasing the pest

Tab. 1. Effect of insecticide treatments in wheat crops (Ariesan variety), ARSD Turda, 2013

\begin{tabular}{|c|c|c|c|c|c|c|c|}
\hline \multirow[b]{2}{*}{ Insecticide treatments } & \multicolumn{3}{|c|}{ Grain yield (Kg / ha) } & \multicolumn{3}{|c|}{ Thousand Grain Mass (TGM) } & \multirow{2}{*}{$\begin{array}{c}\text { Thrips } \\
\text { Larvae/ } \\
\text { ear }\end{array}$} \\
\hline & $\begin{array}{l}\mathrm{Kg} / \\
\text { ha }\end{array}$ & $\%$ & Differ. & TGM(g) & $\%$ & Differ. & \\
\hline 1. ST + Untreated on vegetation & 7763 & 100.0 & check & 54,567 & 100,0 & check & 1,5 \\
\hline 2. ST + T1 & 7710 & 99.3 & -53 & 53,433 & 97,9 & $-1,133$ & 0,0 \\
\hline 3. $\mathrm{ST}+\mathrm{T} 1+\mathrm{T} 2$ & 7922 & 102.0 & 159 & 52,500 & 96,2 & $-2,067^{00}$ & 0,5 \\
\hline 4. Plowing lot without treatments & 4376 & 56.4 & $-3387^{000}$ & 52,833 & 96,8 & $-1,733^{\circ}$ & 21,1 \\
\hline 5. No tillage without treatments & 4590 & 59.1 & $-3173^{000}$ & 49,733 & 91,1 & $-4,833^{000}$ & 28,8 \\
\hline 6. Agro-forestry system (ST+ T1+T2) & 5200 & 67.0 & $-2563^{000}$ & & & & 4,1 \\
\hline $\begin{array}{l}\text { 7. Agro-forestry system without } \\
\text { treatments }\end{array}$ & 5105 & 65.7 & $-2658^{000}$ & & & & 7,7 \\
\hline LDS p 5\% & & 7.68 & 596.76 & & 2,322 & 1,267 & \\
\hline LDS p $1 \%$ & & 10.79 & 837.66 & & 3,378 & 1,843 & \\
\hline LDS p $0.5 \%$ & & 15.23 & 1182.58 & & 5,067 & 2,765 & \\
\hline F Test & & $\mathrm{F}=69 . \mathrm{C}$ & & & $\mathrm{F}=21,33$ & & \\
\hline
\end{tabular}

$\mathrm{ST}=$ seed treatment with Yunta $246 \mathrm{FS}, 2 \mathrm{l} / \mathrm{t}$ TS.

$\mathrm{T} 1$ = field treatment at the end of tillering / 23.04.2013/ with Calypso 480 SC 100ml/ha;

$\mathrm{T} 2$ = field treatment at the ear emergence / 17.05. 2013/ with Faster $10 \mathrm{CE} 100 \mathrm{ml} / \mathrm{ha}$ 
abundance. The wellknown systematic groups of entomophagous predators: Aranea; Thysanoptera (Aeolothripidae); Heteroptera (Nabidae etc.); Coleoptera (Carabidae, Staphylinidae, Coccinellidae, Cantharidae, Malachiidae etc.); Diptera (Syrphidae, Empididae etc.); Hymenoptera (Formicidae etc.); Neuroptera (Chrysopidae) etc. were represented in the structure of arthropod fauna in wheat crops of Transylvania (Malschi, 2007, 2008, 2009).

The integrated pest management researche on the cereal agroecosystems with conservative no tillage soil technology, have recommended the insecticides chimical control, using insectofungicide seed treatment and 2-3 succesive insecticides field treatments (Malschi et al., 2012). The application of special insecticide treatments is required especially under unfavorable agroecological conditions of excessive heat and draught during the critical attack periods, in no tillage and minimum soil tillage technologies (Carlier et al., 2006; Guș and Rusu, 2008; Haș et al., 2008; Malschi et al., 2013 c).

In the last years, two critical attack moments and risk situations (Figures 7 and 8) have been reported to require treatment application (Malschi, 2009; Malschi et al., 2013 b): 1. In April, at the end of tillering in the 25-33 DC stage (at latest of herbicidal treatment), or earlier in some years; insecticide treatment for Diptera and wheat fleas (Chaetocnema), bug and Oulema adults also to reduce thrips and leafhoppers attack potential, has been carried out by using systemic insecticides: neonicotinoids - tiacloprid, thiametoxam, organophosphorous or the pyrethroids etc. At this moment, entomophagous has been at the beginning of its field occurrence and less exposed to insecticides. 2. The treatment in the flag-leaf appearance and ear emergence, in the 45-59 DC stage, in May 10-20, has been applied to control wheat thrips adults (Haplothrips tritici), aphids, bugs and others. The pyrethroids, neonicotinoids etc. achieved immediate control of the pest complex with a long time effect and efficiencies against the development of thrips larvae on the ears and yield increases.

\section{CONCLUSIONS}

The paper presents new research on pest population abundance and integrated pest management (IPM) in winter wheat crops in relation to the climate warming in Transylvania, under different cultural soil technologies: classical (plowing) and conservative (no tillage), in open field agro ecosystems and in agro-forestry belts system, in experimental lots, in the vegetation year 2007-2014. Were pointed out major outbreaks of abundance of thrips (Haplothrips tritici); wheat flies (Chloropidae: Oscinella frit, Meromyza nigriventris, Elachiptera cornuta etc. and Anthomyidae: Delia coarctata, Phorbia securis, Ph. penicillifera); stem flea beetles (Chaetocnema aridula); leafhoppers (Javesella pellucida, Psammotettix alienus, Macrosteles laevis), aphids (Sitobion avenae, Schizaphis graminum, Rhopalosiphum padi, Metopolophium dirhodum); cereal bugs (Eurygaster maura, Aelia acuminata) etc.

The paper mentions the importance of adjusting the IPM technology on the pests structural changes, which is highlighted in relation to climatic warming and aridization by increasing abundance of wheat thrips (as eudominant species), of wheat flies Chloropidae, leafhoppers, aphids, wheat fleas (as dominant groups), cereals bugs etc.

IPM recommends special attention to preventing measures for zone specific pests: cereal flies, leafhoppers, aphids, etc., which still shows a high biological potential, by respecting the optimal sowing time, agrotechnical methods, cultural hygiene, seed treatment with systemic insecticide and the complex plant protection measures.

Due to aridization and climate warming, the critical attack moments have been recorded 3-4 weeks earlier and overlapped. The research results proved the importance of insecticide applications at two different moments: at the end of tillering phase (13-33 DC stage) and at the flagleaf appearance and ear emergence in 45-59 DC stage, in open field area. At the first treatment, the pest groups that focus on spring crops (cereal flies, fleas, leafhoppers, thrips, bugs etc.) are controlled simultaneously, by recommending the shock and systemic insecticides (pyrethroids, neonicotinoid etc.), no later than herbicide applied moment. At the second treatment, the ear pests (thrips, aphids, bugs etc.) are controlled simultaneously and it is strongly recommended the shock insecticides (pyrethroids etc.) with reduced effects on the entomophagous arthropod fauna.

The IPM is a major section of successive soil no tillage technologies, comprising a special pest control strategy, with insecticides application on 
seed treatment and in 2-3 successive treatments in vegetation.

Entomophagous populations are very active and efficient on the pest natural limitation in Transylvania. They are particularly abundant and are represented by an important species diversity on the agro-ecosystems in open field area, both in the classic technological system, but also in soil no tillage conservative system.

In the farming system with protective agroforestry belts - favourable for increasing of useful fauna, the research pointed out the efficiency of biological control, only using the entomophagous natural resources, without insecticides application.

Under risky conditions caused by the attack of pests in relation with climate and regional agro-ecological changes, the IPM objectives are the achievement of yield safety, the attaining economic and ecological efficiency; the protection of environment and food quality; the preservation and use of biodiversity.

Acknowledgements: The authors acknowledge to Agricultural Research and Development Station Turda, to research working groups of technologies and of seed production farm for the support and interest shown on the research.

\section{REFERENCES}

1. Baicu T (1996). Principles of integrated pest and disease management. Ed.Ceres, Bucharest.

2. Bărbulescu A, Popov C (2001). Elaborarea unui sistem de combatere integratã a dãunãtorilor şi bolilor din culturile de grâu şi orz de toamnã, Anale ICCPT Fundulea 68:373384.

3. Bărbulescu A, Popov C, Mateiaș CM, Voinescu I, Guran M, Raranciuc S, Spiridon C, Vasilescu S, Valsan D (2001) Evoluţia unor boli şi dăunători ai cerealelor, plantelor tehnice și furajere în țara noastră, în anul 2000. Probleme de Protectia Plantelor 29(1):1-17.

4. Bărbulescu A, Popov C, Mateiaş MC (2002). Bolile şi dãunãtorii culturilor de câmp, Ed. Ceres Bucureşti, 376 p.

5. Carlier L, Vlahova M, Rotar I. (2006). Reduction of soil erosion and soil carbon and nutrient lesses by "reduced tillage" cultivation in arable land. Bulletin USAMV- ClujNapoca 62:14-20.

6. Cooper T, Hart K, Baldock D (2009). The Provision of Public Goods Through Agriculture in the European Union, Report for DG Agriculture and Rural Development, Institute for European Environmental Policy: London. http://ec.europa.eu/agriculture/analysis/external/ public-goods/summary_en_fr.pdf

7. Guș P, Rusu T, (2008). Sisteme minime de lucrare a solului-alternative pentru protectia mediului. p.9-18. In:
Guș P, Rusu T (Eds.). Soil Minimum Tillage Systems, 5th International Symposium. USAMV CN, Ed. Risoprint, ClujNapoca.

8. Haș I, Nagy C, Haș V, Moldovan V, Mureșan E, Nagy E, Ignea M (2008). Soiuri si hibrizi de grau, soia si porumb pentru tehnologii conservative cu lucrari minime in conditiile SCDA Turda. p. 162-170. In: Guș P, Rusu T (Eds.). Soil Minimum Tillage Systems, 5th International Symposium. USAMV CN, Ed. Risoprint, Cluj-Napoca.

9. Malschi D (2007). Mediu-agricultură-dezvoltare durabilă și managementul integrat al dăunătorilor agroecosistemelor cerealiere. Ed. Argonaut, Cluj-Napoca, $186 \mathrm{p}$.

10. Malschi D (2008). Mediu-agricultură-dezvoltare durabilă. Optimizarea tehnologiilor de management integrat al dăunătorilor grâului în dinamica modificărilor agroecologice din Transilvania. (Environmentagriculture-sustainable development. Optimization of integrated wheat pest management technologies under the dynamics of agroecological changes in Transylvania). Ed. Argonaut, Cluj-Napoca, 315 p.

11. Malschi D (2009). Integrated pest management in relation to environmental sustainability. Part I. Ecological management of wheat pests. Manual online. Faculty of Environmental Sciences, Babeş-Bolyai University, ClujNapoca. Bioflux Publishing House, Cluj-Napoca, 200 p. http://www.editura.bioflux.com.ro/carti-2009/ http:// www.editura.bioflux.com.ro/docs/malschi.I.pdf.

12. Malschi D, Tritean N, Serbănescu R (2010). Protective agroforestry belts and their environmental importance for sustainable agriculture development in Transylvania. Romanian Agricultural Research 27: 103-114.

13. Malschi D, Ivaș A, Ignea M, Tritean N, Chețan C (2012). Integrated wheat pests control in relation with agro-ecological changes and agriculture sustainable development. p. 141-168. In: Petrescu DC, Burny Ph, Petrescu-Mag RM (Eds). Agri-environment: perspectives on sustainable development. Les Presses Agronomiques de Gembloux, www.pressesagro.be, pressesagro. gembloux@ulg.ac.be./Bioflux Publishing House, http:// www.editura.bioflux.com.ro .

14. Malschi D, Ivaş AD, Kadar R (2013) a. Integrated management of wheat aphids and leafhoppers - suitable control methods in Transylvania. Romanian Agricultural Research 30: 317-328.

15. Malschi D, Mureşanu F, Ivaş A (2013) b. Evaluarea potenţialului dăunătorilor culturilor de câmp din Câmpia Transilvaniei. Anale INCDA Fundulea. 79(1):167-183.

16. Malschi D, Ivaş A, Ignea $M$, Chețan F, Chețan C (2013) c. Adequate integrated control of wheat pests in no-tillage conservative system. In: Soil Minimum Tillage Systems, 7th International Symposium. USAMV CN, Ed. Bioflux. http://journals.usamvcluj.ro/index.php/promediu / index. Proenvironment 6:332-341.

17. Popov C (1979) Consideraţii generale privind factorii ecologici care intervin în reglarea nivelului numeric al populaţiilor de insecte dăunătoare din culturile de cereale, Probleme de Protectia Plantelor 7(4):401-423. 
18. Popov C, Trotus E (2000). Prevenirea si combaterea viermilor sârmã prin tratamentul seminţelor, Anale ICCPT Fundulea, 68:215-224.

19. Popov C, Bărbulescu A, Trotuş E, Vasilescu S, Bucurean E (2001). Control of Wireworms by seed treatment in Romania, Romanian Agricultural Research 15: 69-76.

20. Popov C, Bărbulescu A, Vilău F, Trotuş E, Malschi D, Vasilescu S, Trașca G (2003). Influența secetei asupra evoluţiei populaţiilor de insecte daunatoare din culturile de câmp, Probleme de Protectia Plantelor 31(1): 49-66.

21. Popov C, Trotuş E, Vasilescu S, Bărbulescu A, Râşnoveanu L (2006). Drought effect on pest attack in field crops, Romanian Agricultural Research 23: 43 - 52.

22. Popov C, Bărbulescu A (2007). 50 de ani de activitate ştiinţifică în domeniul protecţiei culturilor de câmp, împotriva bolilor şi dǎunătorilor, An. INCDA Fundulea, Volum jubiliar 75: 371-404.
23. Popov C, Bărbulescu A, Raranciuc S (2007). Tratamentul semințelor - metodă modernă, eficientă și puțin poluantă de protecție a culturilor de câmp, An. INCDA Fundulea 74: 133-139.

24. Popov C, Cană L, Georgescu E (2009). Rolul indicatorilor de biodiversitate în aprecierea managementului dăunătorilor din cultura grâului. An. INCDA Fundulea 77: 199-210.

25. Popov C, Cană L, Trotuş E, Stoica V, Vilău F, Trașcă G, Ciobanu $C$ (2010). Cercetări privind îmbunătățirea tehnologiei de combatere a gândacului Zabrus tenebrioides Goeze., prin tratarea semințelor de grâu și orz, An INCDA Fundulea 78(2): 135-151.

26. Wetzel Th (1995). Integrierter Pflanzenschutz und Agroökosyteme. Steinbeis-Transferzuntrum (STZ). Integrierter Pflanzenschutz und Ökosysteme. Ed. Druckhaus Naumburg GmbH, Halle / Saale und Pausa Vogtl. Bundesrepublik Deutschland. 